\title{
Political Opposition in Turkey: An Analysis of the Oppositionist Styles of Necip Fazil Kisakurek and Nazim Hikmet Ran
}

\author{
Hazan Güler Ph.D \\ Student, Research Assistant at Ankara Yıldırım Beyazıt University
}

\begin{abstract}
Opposition culture in a society gives important clues about the socio-political structure of the country. The more a country welcomes differences in its social, political and cultural life; the more it comes close to a democratic regime. Opposition in Turkey, in its long history, has always been problematic because of the domination of statism not only in politics but also in other fields, such as social and cultural areas. In general perception of Turkey, separating from the central opinion has always been equal to chaos, which prevents the development of opposition cult in socio-political life. Supporting the refusal of opposition through some religious factors, Turkish political culture, starting with the Ottoman period, has settled such a limited understanding that it doesn't allow an ideal form of opposition to grow. However it is known that political opposition, if practiced well, can help a political structure to renew itself, to continue development, to have a dynamic management and to reflect the preferences of people as many as possible. All these important points bring the necessity to analyse the social and political opposition culture in Turkey deeply. Therefore this study first tries to take attention to the understanding of importance of opposition culture in the eyes of politics and society. By analysing striking actors in Turkish literature Necip Fazil Kısakurek and Nazim Hikmet, the study aims to underline how the perception of opposition gave harm to political and social development of the country. By the way, this analysis reveals the need for a better understanding and practice of opposition culture for further developments in Turkey. The study starts with a general theoretical framework of opposition; in which the definition and scope of political opposition, different types and importance of opposition culture are explained. In the second part, Turkish political culture and the way it perceives the idea of opposition is revealed from a historical perspective. At the last part Kisakurek and Hikmet, who were the men of letters touching Turkish politics by their poems and proses, are analysed. Seeing similar processes of the two, who had in real completely different ideological backgrounds, the holistic structure of state mechanism against all kinds of differences is to be illustrated.
\end{abstract}

Keywords: Turkish politics, Turkish literature, opposition culture.

\section{Introduction}

Opposition in general terms is a broad concept. It can easily be transferred to social and political fields. Opposition culture cannot be considered independent of social and political structure of a country. The meaning of opposition in Turkish social and political life has been complex. In its historical background, Turkish politics and society haven't been able to welcome differences. In order to analyse the perception of political opposition culture, this study touches two important literature figures that had been effective in Turkish politics for a long time.

The two men of letters, Necip Fazil Kisakurek and Nazim Hikmet Ran are chosen for the study, since both have been important examples of the opposition culture by social and political means. The problematic position of opposition culture in Turkey can be examined by various events or actors. The critical reason behind these actors is to show how Turkish settled perception has given harm to the notion of 'difference'; regardless of different ideologies of Kisakurek and Hikmet.

Starting with the conceptual framework on the concept of political opposition, the study will shortly look at Turkish political culture in the second part and lastly it will examine the poems and writings of Kisakurek and Hikmet. Through analysing their literature and showing their life experiences, it will be clear to see how a limited understanding of opposition has hindered Turkish political and social life. As the method of the study, literature review is targeted for the first two parts; and in the third part Kisakurek and Hikmet's literature works will be evaluated according to a content analysis procedure. 


\section{Opposition as a Political Concept}

Social and political issues are not easy to define. This becomes more apparent in political theory; creates a relative nature in the determination of concepts. Political opposition is one of those concepts, complex in terms of the perception of different fields. Mostly, the term doesn't evoke a positive meaning; it is highly related with exclusion from the generally accepted perception. This may even indicate the difficulty of describing terms in a social and political environment.

As a part of political culture, political opposition is one of the most important topics in social and political sciences. Opposition, in the general framework, means opposing an opinion, attitude and behaviour, being different and disapprobation that view (Turgut, 1984: 3). The presence of two is enough for any opposition. The opposition can be seen at every level in social life. The opposition includes not only the level of conflict of ideas, but also the conflict movements that can occur at the level of action.

When the meaning of the general opposition is judged politically, it turns into a political opposition. In this case, the opposition takes on a political character that targets the existing social and economic construction, the political regime and its concrete objects. It is to counter or block the actions and policies of the government that represent different ideas and interests. To define political opposition in broad terms, it is a procedural act/phenomenon which can occur in a certain social form at any time, by opposing the current political regime and the socio-economic system, or opposing only one of them, or only those holding the political power and/or their activities; providing them with or without an alternative program or proposal, criticizing it by applying to various ways not within the legal limits or by legal means and struggling to create effects and consequences for the desired purpose (Turgut, 1984: 4-8).

In the identification of political opposition, government and government activity is considered as the main theme. Mostly, studies on political opposition include those movements within the parliament and related with power or actions of power in order to dismiss. A political opposition doesn't always mean an opposition among political parties in the parliament, but it can include non-parliamentary actions as well (Turgut, 1984: 135). Therefore, oppositionist can be described as any group of political individuals with the intention and desire to take the place of the executive group in any position. Therefore, political opposition can also be made either by organized or unorganized groups and individuals.

The reasons and the sources of political opposition, as mentioned above, can change. Among these various reasons are the following; to oppose the political regime and socio-economic order, to question all aspects of social construction, to resist only the socio-economic structure or existing regime, to object the pressure of the supporters if they appear to be oppressive, to reject the legitimacy of the person controlling the state or holding the political regime, trying to achieve the desired result by printing features that interest interests without targeting a structural change and rather than a clear and tangible target, just to make some positive returns (Turgut, 1984: 7).

\section{The types of political opposition}

The complex nature of political opposition makes it clear that; concepts as culture and opposition cannot be identified through a fixed framework. Therefore, it is easy to capture the unique formation that political opposition has. The context of opposition in every social and political structure includes a great variety of meaning. It is not possible to think of a single political opposition; rather there are different fractions or types of such opposition. The political opposition can be grouped by more than one categorization, which is; the constitutional/non-constitutional opposition, structural/non-structural opposition and parliamentary/non-parliamentary opposition (Turgut, 1984: 10-18).

For the first categorization (constitutional - non-constitutional opposition), the emergence and the organization of the opposition group may be contrary to the constitution. What determines the opposition is the way it is made; whether the opposition is carried out in accordance with the rules of the system or contrary to the rules. The constitutional opposition can also be defined as in-system, real and loyal opposition; on the other side the non-constitutional opposition can be called as off-system opposition. Because each state can have different practices in terms of constitutionality, the determinant in this categorization can change from one to another (Turgut, 1984: 10-11).

The determination of the structurality is the main motivation for the second categorization (structural - non-structural opposition). When the opposition aims to request for amendment of political structure/regime or request for change in socioeconomic structure/scheme, there occurs a structural opposition, which is also called as the ideological or principal 
opposition. On the other hand, if the opposition aims to request only for amendment of original politics of the power or government, the opposition is a non-structural one, which is traditional and pragmatic (Turgut, 1984: 12-14).

For the last categorization (parliamentary - non-parliamentary opposition), the opposition is based on those people who make the opposition, rather than the place where the opposition is made. What determines the difference between the two is whether the opposers are in the parliament or not. Mostly this category shapes the general understanding on the political opposition. The political opposition is mainly perceived as to take place only in the parliament. As political opposition includes any action by restricting the power by observing its decisions, behaviours and policies or by offering an alternative programme; these can also be practised by actors outside of the parliament. The degree of opposition in which it causes a change in the power of the government is the significant point rather than the actors who make it (Turgut, 1984: 15-18).

\section{Political opposition as the guarantee of democracy}

The simplest definition of democracy by Lincoln's expressions; "government by people and for people" shows a critical relationship between democracy and the culture of political opposition (Lijphart, 2012: 1). In the modern understanding of democracy, since it is the rule of public generally by the majority of the public, the importance of considering the interests of almost all people becomes more apparent. Therefore, the existence and the right exercise of opposition are directly related with the level of development of democracy in a society.

The opposition is vital for the existence of democracy. The relation between the formation of political opposition and political culture in a country becomes relevant with the development of democracy (Turgut, 1984: 92-95). Therewithal, democracy is necessary for the existence of legal and open opposition. The principles of democracy are also the conditions of the existence of opposition. At this point, it is easy to mention that both the political opposition and democracy are the guarantors of each other.

The influence of the political opposition is very important in getting democracy out of its absolute and narrow conception as in the early ages and gaining a contemporary and modern character (Turgut, 1984: 41). The point is that, opposition is one of the main motives of today's modern democratic practices. The existence of a strict, legal and alternative government that keeps the government's work under control is an important determinant of today's modern democracy; and it is provided by the activities of opposition groups. Therefore, it is certain that if political freedoms and legitimate opposition get out of hand, democracy soon ceases.

For the existence of political opposition constitutionally, democracy as apparent from the explanations above is the main necessity. Moreover, political opposition may need some socio-political support to occur. Some of them are the equality in the use of mass media, free and fair elections. High belief and respect for democratic values in the society is another important factor, because what the power understands from the opposition is a critical determiner in the settlement of the opposition perception in a society. The opposition needs to be regarded as legitimate as power (Turgut, 1984: 37-40). So, the understanding of opposition by power also conducts the understanding of the public and affects their attitude. Vice versa the opposition is responsible for shaping the way power and public perceives itself. The opposition groups need to define themselves clearly and observe the power carefully in order to create an ideal form of opposition in the eyes of public. Moreover an opposition, which is out of system aiming to destruct it, cannot be welcomed by power. Therefore, in order to take part in the system, an opposition needs to be systematic, constitutional.

By presenting the perception of opposition as a part of democracy, political opposition undertakes some tasks and duties. Supervision, control and directing power are the duties of the opposition for the government. Moreover its responsibility to the public is to represent the opposition in the parliament and to introduce an alternative managerial staff (Turgut, 1984: 43-45). By the way, the opposition party gives the public the impression that it is ready to handle power; to direct the country at any time and/or in case of the ruling party loses elections or resigns for any reason.

The characteristics of the political opposition become clear so far, which means the opposition is an organized, continuous, alternative, representative, participatory, competitive action (Turgut, 1984: 58-66). The organization of the opposition determines its intensity; when the opposition is concentrated in one hand, the intensity of opposition is high comparing to the division of opposition. The continuity of opposition means a durable position pursued by opposition parties in parliament and non-parliamentary actors outside. The fact that it is an alternative to power substantially identifies the role of opposition against the ruling power. This feature directly causes the competitive nature of opposition in the system. Especially in times of elections, competition is very intensive. The opposition as a participatory and representative agent is valid for any group 
in the parliament. At this point, main areas in which the parliamentary opposition can intensify its activities are public opinion, elections, parliament, coalition processes, bureaucracy and interest groups.

\section{Non-parliamentary political opposition}

Studies on political opposition often deal with the nature of parliamentary opposition when analysing the types of political opposition and the procedures carried out. Non-parliamentary opposition as well as parliamentary political opposition has a wide range. Because it is not possible to limit the non-parliamentary opposition, its expansion is greater and its actors can vary. Youth and student groups, press, social media, intelligentsia, women, minorities, universities, workers, various occupational groups, unions and associations are some of these actors. Non-parliamentary opposition has many forms as; strikes (including not only worker strikes, but also actions referenced in other areas), disobedience with orders, decisions of managers and laws, invasion of institutions such as factories, universities, ministries, parliamentary (all of which include use of force) at various levels, non-participation in elections consciously; meetings, marches, organizing forums, seminars, open sessions, preparing papers and distributing brochures (examples of peaceful ways of political opposition) (Turgut, 1984: 138-139).

The cases in which social opposition is subjected to protest actions and some other peaceful means of seeking to achieve current and concrete objectives can be defined as non-parliamentary opposition. Non-parliamentary opposition has no goal and no institutional task as to seize power through electoral struggle. For this reason, the focus of the government is largely on system criticism rather than the ruling. Among the reasons of the emergence of non-parliamentary opposition include (Turgut, 1984: 140-145); inadequacy of traditional channels of participation in democracies and in particular of classical representation, the spread of politics into new and different areas outside parliament and the re-politicization, another way of questioning political power about what they did and what they did not, the incapability of existing political structures on responding to new demands in the social structure and revealing any kind of corruption at the management level and to put the public opinion.

It would be wrong to see parliamentary opposition as the sole representative and source of the political opposition. Nonparliamentary opposition can also be a major influence on power. Moreover, its task can be more difficult in the whole political culture. The main difference and the prominence of non-parliamentary opposition is that it emerges spontaneously, unlike parliamentary opposition (Turgut, 1984: 146-147). The non-parliamentary opposition also contributes to the functioning of pluralist democracy by enlightening the demands and problems that arise in social structures. In various ways of appearance, it is a critical source of the democracy culture. Necip Fazil and Nazim Hikmet can be given as the examples of this category with regard to the topic. Since these actors had never been the members of parliament and both of them were regarded as important representers of the right and left opposition in Turkish socio-political life; they are to be evaluated in the non-parliamentary political opposition through their writings and worlds of thought. Before analysing their oppositionist tones and impact to Turkish policy, it will be appropriate to give a brief overview of the opposition in Turkish political culture. The understanding of the process on how Turkish policy presents an approach towards opposition culture is believed to contribute to the understanding of the actors mentioned.

\section{Opposition in Turkish Political Culture}

As a matter of political culture, the political opposition is directly related with what a society perceives from this concept and how it applies opposition. In order to understand the meaning of political opposition in Turkey, it is necessary to take a look at the settled culture in Turkish political experience, which has roots from the Ottoman Empire. Political culture that is shaped by the meaning attributed by Turkish society for the politics cannot be distinguished from Turkish social and historical memory. Hereof the existence of opposition, the practice of it, and its comprehension by the public are also related to this cultural memory.

Political culture in Turkey is collectivist as a whole. In a general framework, it can be said to have a statist reflex. The name of this "whole" may be; the state, the ummah, the nation, the public, the national will (Ogun, 2004: 36). Instead of its name or label, the functioning of political culture and its reflection to other areas becomes determinant. The political culture, guided by the state myth and bureaucratic administration tradition, takes its source from essentialist philosophy. All state mechanism is based on the single factuality or reality monopolism principle (Caylak, 2007: 142). On the basis of such monopolism, there is a power issue dominating the politics and culture. Such a political culture is maintained not only by state but also by the public. Even at the community level, there is no libertarian understanding of political culture. 
The roots of the holistic political culture in Turkey date back to Ottoman period. The concept of ordo seculorum (nizam-I alem) shaped Ottoman political culture (Caylak, 2007: 143). The content of ordo seculorum in Ottoman period is that; great significance is attributed to the state as a means of congregation. The interests of state are above everything. The system in Ottoman Empire was based on every nation's establishment of its own order. As a great power, the sultan or khalifa was obliged to adapt the order in universe to the social and political life. The opposition was concentrated on an enemy perception that declares any movement resisting the state as an enemy (Caylak, 2007: 143-144). Through such a practise, the Ottomans aimed to establish order among all nations of the empire; and this culture was brought to new secular Turkish state. As a guarantee of the general harmony of society, the state doesn't change its tendency towards a deviation from the whole, whether the rule is Islamic or secular. So did the new Turkish Republic. After the dissolution of Ottoman Empire, the new state mechanism continued the same holistic reflex with different actors under a different ideology, all of which deeply affected the opposition culture in Turkey.

Political opposition cult has a significant role as to provide a process of dynamic and vivid social production. An ideal political opposition can lead to dissemination of the opposition's understanding from a purely political assumption to a wider area as social life (Ogun, 2004: 301). However, the opposition in Turkey does not have a positive sense, not only politically but also socially. Opposition, associated with "fifth way" or a kind of heresy, has a widespread understanding that its existence will harm society and politics (Mardin, 2017: 180-183). The statist understanding in social and political life of Turkey has spread over many areas. Opposition culture is of the most critical ones with misleading sense that it has. Since the socio-political perception is limited by a holistic view in the country, even a slight difference is not tolerated; rather regarded as discriminator. This causes a distorted and sided power-opposition relationship. The opposition culture is guided by intolerance to the smallest departure that separates itself from the whole. Therefore, any opposing view is accused of as unrest, incitement, and disrupter (Mardin, 2017: 189).

The holistic view in Turkish social and political life is supported even by some religious motifs. Religion is used as an instrument in the formation of such attitude. The fact that Turkish political culture is knit with Islam affected the perception of opposition. The verses of the Koran, which describe the way of salvation in the Islamic community, are adapted to opposition in social and political means. By the way, any separation from the grand picture becomes a kind of sin. Moreover, as a consequence of the perfection of the state and the head of state, the opposition is almost united with the idea that they are against God (Caylak, 2007: 144-145). Such a relation between religion and opposition has made the opposition even more problematic.

The formation of a non-exclusive opposition cult is possible only if the opposition gains legitimacy in the cultural codes of the society. What the political culture in Turkey has made is to create a network of pressure and controlling over the opposition, therefore it didn't allow an inclusive understanding of opposition (Mardin, 2017: 175-176). The opposition could only be related with a kind of resistance to the rulers, to the limits of the power. It had no choice but to define itself through a resistance theology. Such a resistance has risks for the democracy in the country, because a healthy opposition is necessary for society and politics to evolve in the direction of democracy.

Supporting the central idea, which is the only truth for the state and society, have become the characteristics of the opposition in Turkey. Since the ruler-managed, centre-periphery or power-opposition relations are all shaped by the social and political stratification, the opposition cult has never developed (Mardin, 1992: 22). Even the political parties are established according to this stratification in Turkey. This was achieved neither in 1946, the date of the transition to democratic life in Turkey nor after 1980s, in which diversity and pluralism were provided by means of identity.

The power-opposition relationship was shaped in two directions in Turkish Republican period. The first one was based on opposition movements defending the market against government intervention and the other was opposition movements that defend traditions and religious beliefs against the state (Caylak, 2017: 148). With a brief look at the opposition experience in Turkish republican history, it is possible to capture the general perception of opposition culture. At the beginning of Republican period, Progressive Republican Party was the first opposition party against Mustafa Kemal Ataturk, the founder of the new state. The main argument of the party was based on the idea that gathering of all the forces in the parliament would lead to authoritarianism. Moreover, in 1930s Free Republican Party became the second opposition initiative, which could only exist as a guided party. When it started to leave from the desired guided party form, the party was forced to dissolve itself (Mardin, 2017: 178-179). All these were enough to see that opposition in Turkey couldn't be absorbed. 
After transition to democratic life in 1946, all the oppositions against CHP (Republican People's Party) were united and represented in the DP. It means through DP, an opposition bloc was formed. Therefore, DP was a broad but nonhomogenous opposition (Caylak, 2007: 152). In real, DP was not an opposition party. Defining DP as an opposing party is equal to accept its success as an opposition in Turkey's political culture. DP's case cannot be considered as a success of opposition because the opposition in Turkey has never had legitimacy in the eyes of the elite and masses. On the contrary, what brought the party its success was more than an oppositionist attitude. According to Mardin, "It would be wrong to define the DP as an opposition in terms of large masses in Turkey." (Mardin, 2017: 188). According to this view, DP and such parties have been the ideal examples of the dreams of rural areas against the representatives of the bureaucracy and the great tradition, for centuries.

The process that affects today's opposition culture, as seen, has a long history. In this respect, it is apparent that the level of tolerance for differences in Turkey is very low, whatever the dominant ideology is. Such problematic air causes a twosided understanding as power vs. opposition. Making both sides confronting against each other, it is clear that there is no constructive political opposition mechanism in Turkey, but rather a dividing cult, settled in the veins of community. For the placement of opposition culture at the socio-political level, the synchronicity of social variables with institutional change is a 'must' (Mardin, 2017: 190).

Having a brief idea on the political culture of Turkey can make it easier to understand the two actors of this study. Necip Fazil Kisakurek and Nazim Hikmet are two important figures of their period as to illustrate the opposition cult in Turkey. Political repression in the country during the Republican period pushed thinkers into the fields of literature and culture. From this point of view, Necip Fazil as the representative of conservative segments and Nazim Hikmet as representative of the communist groups in the society were critical examples of intellectual opposition. As mentioned above, for the traditional political culture of Turkey, the side of opposition was in no importance; rather it was essential to remove any difference. At this point, Kisakurek and Hikmet, despite their totally different ideologies, were regarded as opposite to the state mechanism and therefore exposed to pressures. Thanks to their efforts, the two constitute an important example of this cult. By choosing actors from different areas, this study tries to show the weakness of the opposition culture in Turkey. In the light of these, how these two names developed their oppositionist theories as representative of critical segments in the country; and how they contributed to the opposition culture through their language and unique styles is aimed to be the focus point of the following titles.

\section{Necip Fazil Kisakurek and His Opponent Language}

Necip Fazil Kisakurek is one of the most important thinkers of Turkish-Islamic civilization, besides being a poet, play writer and novelist. Born in 1904, Kisakurek had the opportunity to improve himself thanks to the education he received both in the country and abroad (Okay, 2005: 9). Creating many works in different literary genres, Kisakurek had later touched to social, religious and political issues of his society. His bringing Islamist thinking into the forefront and his criticising the regime because of the anti-Islamist acts caused Kisakurek to be regarded as a great threat for the newly established state. Kisakurek was accused of being a long-time opponent under the structured authoritarian state, so he had a difficult life (Karatekeli, 2014: 4-20).

Turkish Republic, with the aim of spreading a new, modern understanding of nation, state and government, made nearly everything to supress differences that are against its holistic position. In this respect, cultural publishing became important as a means of political critical discourse. One of the most important representatives of this movement was Kisakurek with his numerous works, in which he blamed the regime for erasing the history of society and trying to fill their minds with full of modern concepts, unfamiliar to the society. In his period, Necip Fazil Kisakurek became an important actor of intellectual opposition, with a conservative perspective.

As a political activist, Necip Fazil's real suffering began in 1943 when he started to publish Great East (Büyük Doğu)1, in which Kisakurek gave his intellectual struggle against the political elites openly. He was accused of making opposition during the single-party period due to his writings in the journal. The journal was closed many times and Kisakurek was

\footnotetext{
1 DP is a political party established on 7 January 1946, which remained in the minority in the elections held in the year it was founded and ended the 27-year single-party government in the elections held four years later (14 May 1950). It was an important political movement that formed the opposition bloc against the sing-party government of CHP. Its ideological background was based on the unity of all oppositions in the country.
} 
sentenced to prison several times; totally 3 years 8 months in jail. Moreover, his conflict didn't come to an end with Democratic Party1's power. Even though the party gained the support of those, opposing to CHP's one-party government; DP couldn't meet with Kisakurek at the same ground. He constantly criticized the DP government in order to lead it in a moral way. The whole intention in his criticism was to save the DP from those cadres who couldn't get rid of the CHP mentality and to prevent the DP from being similar to them, when the CHP hatred in the country gained victory. However the DP government caused most of his sufferings by sending him to jail (Duran, 2005: 75-78).

The intellectual opposition through journal publishing united in Büyük Doğu which was a new initiative for the conservative communities. Kisakurek's critical plays addressing the repressive ruling; his books and poems trying to depict Turkey's condition; all attracted the interest of pious, conservative segments of Turkish society. Conservatism, which is exposed to the label 'other' in the early periods of the Republic, created a basis for the questioning of prototype regime (Emre, 2005: 48-49). As the advocate of this idea Kisakurek was, in the eyes of government, an opponent who discriminated himself from the centre.

"In the case of freedom, all humans unite / And freedom is captured by the Sultan of truth" (Öfke ve Hiciv, 237). If his language is started to be evaluated through some of his verses, what actually Kisakurek conflicts against becomes apparent. Rather than the existence of a unity among the public, he tries to make us question the formation of unity. Rather than the existence of freedom, he takes the attention to freedom captured by so-called truth monopolism. Choosing Kisakurek, as a critical actor in the understanding of opposition culture in Turkey, is significant to reveal the main goal of the study within the quoted lines.

He calls the situation, into which the Turkish Islamic communities were forced to drag by Kemalist regime ${ }^{2}$ during the republican period, a felix culpa, meaning a happy fault (Kisakurek, 1969: 7; Kisakurek, 2014: 377-378). What the new state worked for was to create a kind of society, filled with Western morals, values and attitudes, according to Kisakurek. However he believed that no element adopted from the West could reflect the spirit of Turkish society. Therefore, any kind of reform movement that is contrary to the political, cultural, social and even economic structure of the Turkish-Islamic civilization is a kind of Felix Culpa. He didn't hesitate to mention that "the notion of political and social engineering of the new state made it easier for the West to transform the Turkish nation into a colony without even necessity of any military power" (Kisakurek, 1990: 206).

The language, the dominant tone of Kisakurek could be very harsh when criticising the government, which is the main reason behind his attribution as an opponent. His opposition operates to worldliness by spiritual means. "After so much historical sufferings and adventures, aimlessness has completely flopped down on us in the last period; it has affected our failures that are political, administrative, economic, economic and moral; and gave birth to today's scene" (Kisakurek, 2013: 34). Constructing his oppositionist ideas on to moral base, Kisakurek made us evaluate the process from a different perspective. In another phrase from Kisakurek, it is possible to see his tone; "Political, administrative, intellectual, scientific, commercial and legal ethics, together with morality, are at the last stage of the collapse..." (Kisakurek, 2013: 12). He compared the moral status of Turkish community in the process following the establishment of the modern state, with Roman and Byzantium societies, all of and he found them even better than Turks.

As understood from Kisakurek's expressions, the modernization project that started with the Tanzimat period ${ }^{3}$ turned into a colonization process with the Republic by spiritual means. Also in material terms (cultural imperialism), it was almost a semi-colonization process for Kisakurek (Kisakurek, 1952). In order to make a change possible in the government's practices which aimed to create a new Turkish nation from scratch, he formed an intellectual criticism. By harshly revealing what the ruling elites caused, he tried to develop a sense of opposition. "Knowledge, where can it stay when the cognition

\footnotetext{
${ }^{1}$ Kemalists are the ideological supporters of Mustafa Kemal Ataturk, the founder of Turkish state. Kemalist regime is the ruling of CHP, started with Ataturk and continued by Inonu after Ataturk's death. The political framework of this ruling is based on Kemal Ataturk's ideals and principles.

2 The Tanzimat, literally meaning reorganization of the Ottoman Empire, was a period of reformation between 1839 and 1876 under the reigns of the sultans Abdülmecid I and Abdülaziz. The reforms, heavily influenced by European ideas, were intended to effectuate a fundamental change of the empire from the old system based on theocratic principles to that of a modern state.

${ }^{3}$ Ismet Inonu, who was elected as the second President of Turkey by Turkish assembly after the death of Atatürk in 1938 also became the Chairman of the CHP. He received the title of "National Chief" in the same year. It was a kind of declaration of CHP that Inonu became the sole determinant of the country's politics from then on.
} 
is broken? ... You cannot find any place of the country's knowledge of history, philosophy, politics, law, economics or anything else on account of country" (Kisakurek, 2013: 13). For Kisakurek, such values are the main components of a society; the deprivation of society from these major morals can easily turn it into a vain.

Most of Kisakurek's opposition stems from moral, cultural, intellectual and religious concerns. Since he believed that all these factors were the determinants of political practices, formation of culture was of great importance. For this reason, most of his criticisms in his works were built on this notion. Basically, how the state mechanism restricted his thoughts create the main argument of this study. Since he started to reveal his ideological identity, Kisakurek was considered as a "man to be threw of" by the regime elites. The bitter days in which Necip Fazil was forced to live because of his thoughts can constitute the summary of the opposition culture in Turkey in the Republican period. Kisakurek, who did never hesitate to express his dissenting opinions against the government, was in the focus of Kemalist rule.

The process, in which Kisakurek struggled a lot, is an important sign of the holistic Turkish political system. Whatever its ideology is, the state structure has always been against different voices. Kisakurek's criticism of CHP and DP differs in theory but it can be perceived as the same in practise. His criticism of the CHP government was to oppose the change of society under the republican elites, who tried to create a new nation. Kisakurek aimed a structural basis. On the other side, his criticism of DP was based on the purpose of the restoration of lost values. His efforts were to have a better ruling system under DP, but he was misunderstood and this again caused a troubled life for Kisakurek. In this study, rather than blaming DP or CHP, it is aimed to understand the situation by looking at the settled perception of opposition in the codes of Turkish social and political life.

\section{The Oppositionist Tone in Nazim Hikmet}

Nazim Hikmet Ran born in 1902 is a Turkish poet, play writer, novelist and memoirist who is called a romantic communist or romantic revolutionist. He had made great contributions not only to Turkish literature but also to the social and political life in Turkey. Starting poetry at a very early age, Hikmet touched many subjects throughout his life with his poems; and formed a critical example of opposition against the statist political culture in Turkey. Hikmet's influence in various areas continues even today although it has been many years since his death.

Nazim Hikmet has been a significant actor in the analysis of Turkish social and political processes. His way of opposition was through his art like Kisakurek. He saw the art for society and even politics, but never for art's sake (Gok, 2009: 363365). During his struggle, Hikmet never hesitated to express his oppositionist ideas through his poems. "I am a poet / I wrote poems for a year of rain / But / In order to start / My actual masterpiece / I am waiting to be the hafiz of Capital" (Şair, 1923). Quoted verses written at the very beginning of Hikmet's career reveal his initial oppositionist tone.

Nazim Hikmet, who wrote articles and poems in many subjects from everyday events to national problems, also started a war against the literary insights of the sovereign classes and the imperialists. Since he thought that real art should be for the people, through his works he pointed out the struggle in order to give a better world to the oppressed and the exploited; repeated many times that the guide of liberation was in Marxism. As a milestone in the shaping of his life, Hikmet went to Russia in order to see socialist regime with his own eyes. His interest on socialist ideas, the theme of rights of workers and so on appeared firstly when he was appointed in Anatolia as a teacher. After returning to the country, he became a member of TKP (Communist Party of Turkey). "I am a member of the Communist Party of Turkey since 1923; this is the only thing I glory. In the history of the world, it will be difficult to show a single author who is totally neutral and passive in the face of the problems of the age. It can be assumed that he/she is unrepentant and it can be said, but he/she can never be objectively unbiased." As seen in his words, Hikmet never chose to confront the central ideology and abstained from expressing his ideas clearly, even though he very well knew that they were all against the settled perception of the ruling elites (Rizayev, 2009).

When CHP's single-party government was under the influence of rising fascism in Europe, a repressive state policy was established. The state was promoted to a position "above the class" and a fascinating direction was introduced aiming at the unity of the party and the state under the leadership of the "national chief"1. In a period in which the prohibitions and

\footnotetext{
1 Barrasso (2013, September 11). Make the case for Europe. Daily News of 2013.09.11 European Commission- 11/09/2013. Retrieved from http://europa.eu/rapid/midday-express-11-09-2013.htm
} 
pressures increased greatly, since it was already forbidden to propagandize communist ideas through the media in the 1925s, Nazim Hikmet was interrogated, arrested and subjected to various pressures.

"Deceased / Killed by fighting / Buried in the sun / We have no time to keep their math! / There is a flock / Flock to the sun! I We will capture the sun / Close, the capture of sun" (Güneşi Içenlerin Türküsü, 1924). These verses are important as the sign of Hikmet's opposing views against Kemalist rule that he claimed to have killed his comrades. The Law on the maintenance of order (Takrir-i Sükun), issued in 1925, hindered the development of ideas in the country; and stopped the intellectuals who would guide those left in silence. However, with the abolition of this law in 1928, new ideas became available to be written and discussed; and the process was initiated by Hikmet's poetry (Candir, 2011: 167).

Starting to contradict with the party management, Hikmet and his oppositionist friends were dismissed from TKP, which caused Hikmet not to recognise the party and not to continue his communist struggle through it. The fact that he was thrown out of his post didn't hinder Hikmet to express himself through politics-oriented poems and plays. "Living is no joking matter ... / You will take life seriously / Such an extent that / For example your arms tied from the back and your back at the wall ... / You'll die for people / For people whose face you did never see / Even when nobody forces you to do so / Knowing that the best and the most real thing / Is to live" (Yaşamaya Dair, 1947).

As an oppositionist against the regime of Turkey and its ruling elites, Nazim Hikmet had a life full of punishments. He continued his propaganda against the growing state mechanism in the country through making his art during the times he was in prison. "My darling, they are enemies of hope ... / The enemy of developing life / Because they take death mark ... I And of course my darling / Freedom in my beautiful country / Will walk freely / Will walk with the most glorious dress, the boiler suit" (Düşman, 1945). He took advantage of the amnesty law and found freedom after 13 years and 5 months.

The notion of opposition in Turkish political culture didn't make any discrimination among ideologies, as mentioned before. Thus, what Hikmet argued was that the same statist structure was continued even after Democratic Party government. When DP won the power on 14 May 1950, it was a kind of hope not only for Hikmet but for all kinds of differences, who tried to survive against the regime. The only thing that changed was the main ideology of the state mechanism, as happened in the transition from the Ottoman Empire to the republican Turkey. Nazim, who reacted to Turkey's becoming a partner in American imperialism, this time criticised DP government through his poems and writings. When Turkish government decided to send troops to the Korean War in order to be a part of NATO against the USSR, Hikmet wrote the following verses; "Life is a bit expensive in our country / For example, you can get two hundred and fifty grams of meat / Mutton / For 23 cents in Ankara / Or two kilos of dry onion / Or a little more than a lice of lentils /Or fifty centimetres shrouded cloth / Or a man / For a period of one month / Who is about his twenties" (23 Sentlik Asker'e Dair, 1953).

Despite being removed from citizenship, Nazim Hikmet continued revealing his ideas via his art. As an answer to a newspaper article, which called him a traitor, Hikmet wrote a poem, which was kind of a measuring patriotism; "Yes, I am a traitor, you are a patriot, you are a patriot / I am a traitor, I am treasonous, I am treasonous / If your homeland is your farms / If homeland is your cases, your cheque books ... / If it is not to escape from stinking darkness / Yes, I am a traitor I Write with bold font sizes that / Nazim Hikmet is still continuing his homeland treason" (Vatan Haini, 1962).

The quotations from Hikmet are just a few of the works that show his oppositionist attitude. In most of his works he uncovered critical points, most of which caused his troubled life. In fact, Nazim Hikmet's reaction neither targeted the Kemalist rule nor the DP power. His oppositionist attitude was against the process, which adopted a holistic reflex restricting freedoms, regardless of the ideological status of the state. Since he never settled with the state's central perception, he, as a representative of socialist and communist groups, was considered an opponent. Because of these reasons, he wasn't welcomed in Turkish social and political memory for a long time. Due to the placement of opposition culture as a dangerous act in the depths of socio-political codes of Turkey, Hikmet can be handled as a figure, whose value was only appreciated in the eyes of the public after a long time.

\section{Conclusion}

Turkish political culture, with a collectivist structure, has been determinative in the formation of opposition. Due to this holistic understanding, neither political nor the social organs can easily accept the opposition; and opposition culture in Turkey cannot develop. The process started with the Ottoman Empire and is continued with the new republic up to today. Both in politics and society, anything different is considered to be dangerous. The opposition culture is never evaluated as to contribute to pluralism, but rather it is otherized. 
Within this context, it seems significant to analyse the concept of opposition in Turkey by depicting past grief experiences in order just to avoid similar situations in the following period. Therefore this study, after having an idea on how Turkish opposition culture has come to its position, examines the experiences of two thinkers, Kisakurek and Hikmet. The two names contributed a lot to the opposition outside the parliament and they were supressed by the ruling elites for several times. What is interesting is that the schoolmates Kisakurek and Hikmet, even though had completely different political views, were exposed to the same oppressions. The processes they had were similar; life in jails, crime of thought and prohibition of publications. The examples of their hard times can be increased, but the point to focus is the attitude of state mechanism against any difference, regardless of its shape whether conservative or socialist. Because of the opposition culture, which cannot find itself a proper place in Turkish social and political memory, the values of the two great men of letters have been understood too late in this country. Thus the importance of opposition becomes clear; allowing all differences and variants to occur freely will only contribute to the development of this country socially, politically, culturally and even economically.

\section{References}

[1] CANDIR, Muzaffer (2011). İslami Duyarlıı̆ı̆ Cumhuriyet Devri Türk Şiirine Yansımaları (1923-1950), Sosyal Bilimler Dergisi, 9 (1), 165-186.

[2] CAYLAK, Adem (2007, Summer). Türkiye'de Siyasal Muhalefet Kültürü, Türkiye Günlügü, No: 89, 140-153.

[3] DURAN, Burhanettin (2005). Kısakürek'in Siyasi Fikirleri Üzerine Bir Değerlendirme, Hece, Year: 9, No: 97, 7582.

[4] EMRE, Akif (2005). Büyük Doğu ve Gelecek Tasavvuru, Hece, 97. Year: 9, No: 97, 48-55.

[5] GOK, Salhadin (2009). Tek Parti İktidarında Basın Muhalefeti: Millet Dergisi Örneği, A.Ü. Türkiyat Araştırmaları Enstitüsü Dergisi, No: 41, 351-384.

[6] KARATEKELI, Hakkı (2014). Necip Fazıl Kısakürek, İstanbul: Işık Publications.

[7] KISAKUREK, Necip F. (2014). İdeolocya Örgüsü, İstanbul: Büyük Doğu Publications.

[8] KISAKUREK, Necip F. (2013). Türkiye'nin Manzarası. İstanbul: Büyük Doğu Publications.

[9] KISAKUREK, Necip F. (1990). Başmakalelerim 1, İstanbul: Büyük Doğu Publications.

[10] KISAKUREK, Necip F. (1988). Öfke ve Hiciv, İstanbul: Büyük Doğu Publications.

[11] KISAKUREK, Necip F. (1969, July). Felix Culpa-Mesut Suç, Büyük Doğu, Year: 14, Number: 3.

[12] KISAKUREK, Necip F. (1952, July). "Tarih Hükmü", Büyük Doğu, Year: 9, Number: 74.

[13] LIJPHART, Arend (2012). Patterns of Democracy: Government Forms and Performance in Thirty-Six Countries, Second Edition, New Heaven and London: Yale University Press.

[14] MARDIN, Serif (2017). Türkiye'de Muhalefet ve Kontrol, Türk Modernleşmesi: Makaleler 4, (Ed., Mümtaz'er Türköner \& Tuncay Önder), İstanbul: İletişim, 175-192.z

[15] MARDIN, Serif (1992). Türkiye'de Toplum ve Siyaset, İstanbul: İletişim.

[16] OKAY, M. Orhan (2005). İnsan, Sanatçı/Şair ve Düşünür Olarak Bir Necip Fazıl Kısakürek Portresi, Hece, Year: 9, No: $\quad 97,8-15$.

[17] OGUN, Süleyman S. (2004). Türk Politik Kültürü, İstanbul: Alfa Yayınları.

[18] RAN, Nazım Hikmet (2017). Bütün Şiirleri, 13. Edition, Ankara: Yapı Kredi Yayınları.

[19] RIZAYEV, Anar (2009). Nazım Hikmet: Kerem Gibi, (Trans. İmdat Avşar), Ankara: Bengü Publication.

[20] TURGUT, Nükhet (1984). Siyasal Muhalefet Batı Demokrasileri - Sosyalist Ülkeler - Türkiye, Ankara: Birey ve Toplum. 